\title{
Local Reactions Concerning Serbia's Obedska Bara Nature Reserve
}

\author{
Dragoslav Pavić1, Dejana Jakovljević²*, Aleksandar Krajić ${ }^{3}$ \\ ${ }^{1}$ Faculty of Sciences, University of Novi Sad, Trg Dositeja Obradovića 321000 Novi Sad, Serbia \\ ${ }^{2}$ Geographical Institute "Jovan Cvijić" Serbian Academy of Sciences and Arts \\ Đure Jakšića 9, 11000 Belgrade, Serbia \\ ${ }^{3}$ Independent researcher
}

Received: 9 February 2015

Accepted: 5 November 2015

\begin{abstract}
The attitudes and awareness of local residents toward protected areas have been at issue during the last several years. Understanding the awareness and attitudes of people toward protected areas and their integration into management strategies is a key factor in developing successful management plans for long-term conservation of these areas. The goal of this study is to examine the attitudes of local residents toward the Obedska Bara Special Nature Reserve in Serbia, in order to evaluate and ensure the appropriate implementation of protective measures. The field data collection used 218 indirect communications with respondent questionnaires in the villages of Obrež, Ašanja, Kupinovo, Grabovci, and Ogar on random sampling. The questions were divided into two main categories: general questions (gender, age, education, employment, income) which gave socio-economic structure, and questions about the reserve. The second category of questions was used for assessment of awareness of people about the protected area, their attitudes toward protection, attitudes toward tourists, and their proposals for sustainable development of this protected area. Respondents were aware of the presence of the protected area (almost 100\%) and a high percentage of them knew its boundaries. They had a positive attitude regarding protection, but they were not satisfied with protected area management because they felt excluded from protected area issues and they were in some cases in conflict of interest with the authorities of the protected area. They also had a positive attitude toward tourists despite the small benefits. The respondents thought that in future tourism could provide sustainable development of this protected area.
\end{abstract}

Keywords: Obedska Bara, protected area, residents' attitude, Serbia

\section{Introduction}

The attitudes and awareness of local residents toward protected areas have been current issues during the last

\footnotetext{
*e-mail: d.jakovljevic@gi.sanu.ac.rs
}

several years, but interest in environmental attitudes began at the beginning of 1970 [1]. Studies about these issues are related to the concept and principles of sustainable development. Understanding the awareness and attitudes of people toward protected areas and their integration into management strategies is a key factor in developing successful management plans for long-term conservation 
of these areas. Most of the emphases in understanding the perceptions of people have been on the conflicts that exist between people and protected areas. When the institution of a natural protected area is perceived by local residents as limiting and even threatening the local economy, or when it is perceived by local communities as an imposed decision or as unfair interference by national or supranational authorities into local affairs, it is possible that a group of local residents will manifest a negative attitude and opposition to the institution of natural protected areas.

Communities can oppose natural protected areas for a number of reasons, including: forced displacement and prohibited use of commonly used natural resources, establishment of a natural protected area without previous consultation with affected populations or communities, and exclusion from design and implementation of natural protected area management policies. When people feel excluded from the establishment of a natural protected area in a territory that, for historical, customary, or legal reasons belongs to them or they perceive it as such, they assume that an "outsider" establishes it from the part of a group external to their community, with contrary objectives and interests. Natural protected areas are also caught between the competing views of the indigenous people inhabiting them, the dominant social/political classes of the countries where they are located, and the international agencies that promote them. Moreover, the formation of natural protected areas creates debates over whether or not the rights of indigenous people to the natural resources inside them take precedent over the rights of nations in which they are located that are typically more recent [2-7]. Due to all these problems and conflicts between local residents and protected areas, numerous studies which have researched the perceptions of local residents, attitudes, awareness, and opinions toward protected areas have been conducted all over the world.

Among European countries, these studies have been most prevalent in Greece. The study of the attitude of local residents regarding the ways of management and exploitation of the wetlands and their sociological features was carried out in communities neighboring four Ramsar wetlands in northern Greece: Evros, Nestos, Koronia, and Lake Mitrikou [2]. Perceptions and awareness of citizens were studied in the following protected areas in Greece: The National Park of Eastern Macedonia and Thrace, the Wetland of Kalloni, and Lake Tavropou [8]. Representation by rural people of 'nature,' 'wildlife,' and 'landscape' were studied in the Dadia Forest Reserve in Greece [9]. Opinions of landowners of buffer zones around forest reserves toward conservation were studied in southern Sweden [10]. A study in Poland assessed public acceptance of the expansion of nature conservation in the context of sustainable development principles and discovered whether existing nature governance should be modified in establishing new protected areas [11]. Local and non-local residents' attitudes toward protected areas were examined in Gennangertu National park in Sardinia and the Tuscan Archipelago National Park in Italy [7]. Local residents' attitudes and opinions toward nature protection and place attachment were studied in two national parks: Šumava in the Czech Republic and Pelister in the Republic of Macedonia [12]. The importance of local community involvement in protected area management was emphasized in a study of the Slovakian national park system [13].

There are 428 protected areas in Serbia, with a total surface of 531,571 ha, which represents $6.2 \%$ of total surface of the Republic of Serbia [14]. There have been many studies about these protected areas, but surveys about the relationships between protected areas and local residents are still rare. There are only two studies (from Tara and Kopaonik national parks) that have considered this issue. The results of these studies showed negative attitudes of local residents toward Tara and prevailingly positive attitudes toward Kopaonik. The results also indicated that attitudes depended on some socio-economic variables (age, gender, education, and whether they have worked for a national park or not) in Tara, and conflicts between local residents and authorities in Kopaonik because of a ban on bilberry gathering [15-16].

The goal of this study is to examine the relationship between Obedska Bara and local residents in it: awareness and attitudes toward protected area, tourists, problems, and sustainable development of this area. Field data collection, based on questionaries, has great importance in determining the attitudes of local residents toward protected areas. Direct conversations between examiner and respondents provide more relevant data than other kinds of similar questionaries (e-mail questionaries, for example). Advantages of direct communication include possibilities that the examiner give additional explanation of questions, as well as more detailed answers by respondents. The attitude and support of local residents towards the protected areas can potentially determine the success of implementation of protective measures. In the case of prevalently negative attitudes toward protected areas, actions can be undertaken to increase the support and understanding of protective measures.

\section{Study Area}

The Obedska Bara Special Nature Reserve (Fig. 1) is part of the wetland habitats along the Sava River that extend through Croatia, Bosnia and Herzegovina, and Serbia. It is located in Pannonian Serbia along the left Sava riverbank, in the south Srem, within the municipalities Pećinci and Ruma, from $44^{\circ} 38^{\prime} 02^{\prime \prime}$ to $44^{\circ} 46^{\prime} 05^{\prime}$ N and from $19^{\circ} 47^{\prime} 16^{\prime \prime}$ to $20^{\circ} 03^{\prime} 30^{\prime \prime} \mathrm{E}$ with central coordinates $44^{\circ} 43^{\prime} 20^{\prime \prime} \mathrm{N}, 20^{\circ} 01^{\prime} 30^{\prime \prime} \mathrm{E}$. The altitude of the Reserve is between 71 and $82 \mathrm{~m}$ above sea level.

Obedska Bara is one of the oldest protected areas in the world. The first administrative protective measures were introduced in 1874, when the Habsburg Empire protected it as royal hunting grounds. The Yugoslavian Government protected this area in 1919 for the first time as the hunting ground of the royal Karadjordjević dynasty, and in 1951 as a reserve. The municipality of Pećinci first 


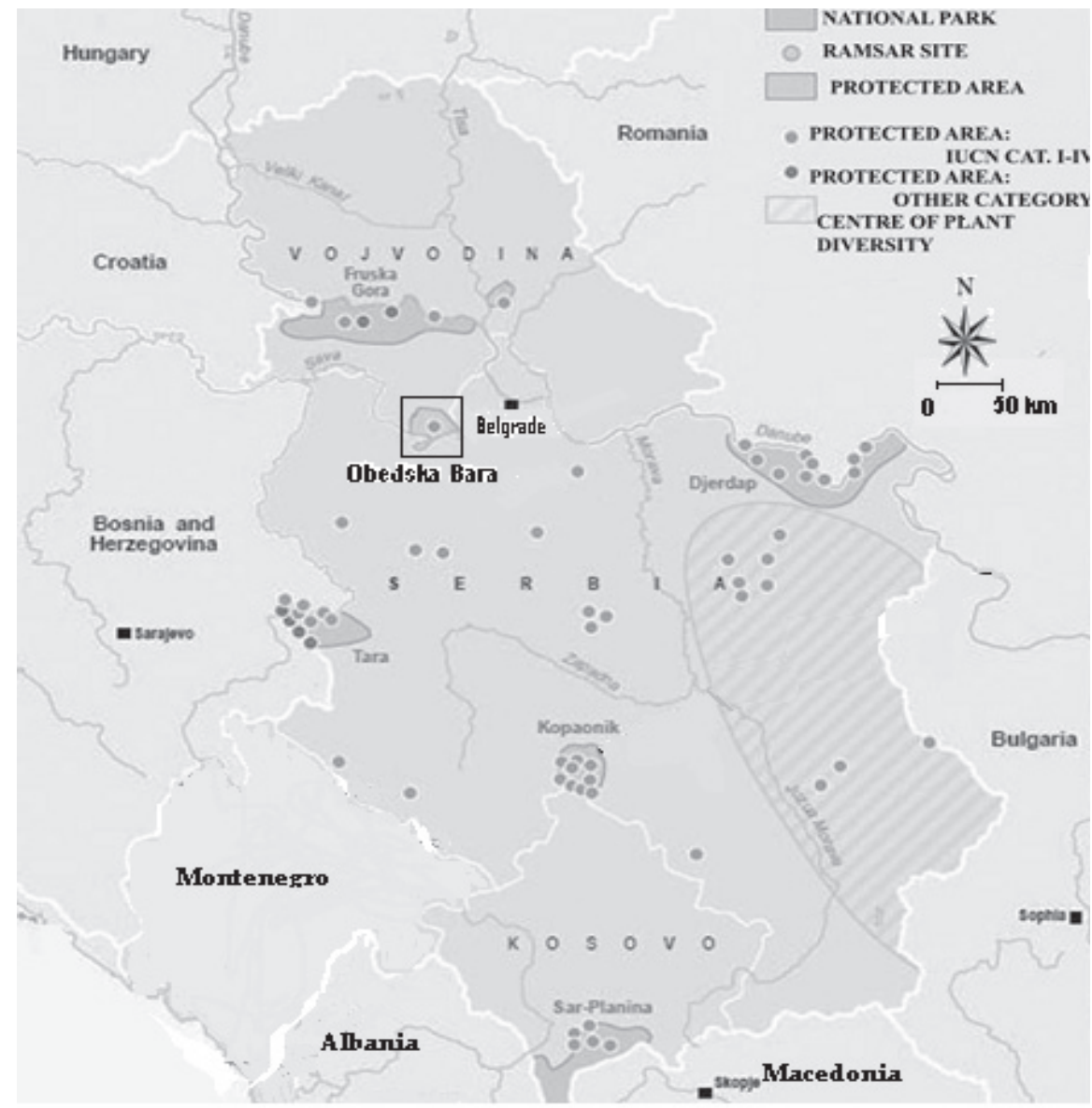

Fig. 1. Geographic position of Special Nature Reserve "Obedska Bara" in Serbia.

protected Obedska Bara as a special nature reserve in 1968. Presently it has held first-category legal protection status, denoting a natural asset of exceptional value with total surface of 9,820 ha, since 1993. Its status has been verified by the Ramsar Convention on swamps since 1977, and it has been on the list of areas of special significance for birds of Europe of Important Bird Area Project since 2000, which consists of the Obedska Bara and its buffer zone. It is also on the UNESCO list of the world's most important wetland areas.

Obedska Bara involves complexes of wet meadows and forests, agricultural lands, and the villages of Kupinovo, Ašanja, Obrež, Ogar, and Grabovci. The essential natural value of Obedska Bara is ecosystem integrity of marshes, ponds, wet meadows, forest, an oxbow, and stagnant tributaries and pits - all within an extremely rich ecosystem and species biodiversity, which is characterized by the presence of rare and endangered species of national and international significance. More than 500 species of plants are found in the area, which consists of numerous sensitive (fragile) ecosystems, especially wetland and ancient forests of pedunculate oak (Quercus robur) and Italian oak (Quercus frainetto) with associated species of ash (Fraxinus) and elm (Ulmus). The bird fauna features some 250 species, including: black stork (Ciconia nigra), white-tailed eagle (Haliaeetus albicilla), lesser spotted eagle (Aquila pomarina), black kite (Milvus migrans),
European honey-buzzard (Pernis apivorus), white stork (Ciconia ciconia), saker falcon (Falco cherrug), hobby (Falco subbuteo), common kestrel (Falco tinnunculus), black-crowned night-heron (Nycticorax nycticorax), grey heron (Ardea cinerea), purple heron (Ardea purpurea), little egret (Egretta garzetta), squacco heron (Ardeola ralloides), pygmy cormorant (Phalacrocorax pygmeus), and Eurasian spoonbill (Platalea leucorodia). Mamal fauna is comprised of 50 species, including: otter (Lutra lutra), wildcat (Felis silvestris), pine marten (Martes martes), golden jackal (Canis aureus), and European beaver (Castor fiber). There are also 16 fish species, including northern pike (Esox lucius), weather loach (Misgurnus fossilis), crucian carp (Carassius carassius), and carp (Cyprinus carpio).

Anthropogenic values in the protected area are remnants of the medieval fortress Kupinik, the monastery Obed, St. Lucas Church, ethno park, the Church of the Venerable Mother Angelina, and Kupinik hunting-ground.

There is a three-level protection regime in the reserve and buffer zone around the reserve (Fig. 2). The first protected zone includes 315 ha, the second protected zone includes 2,565 ha, the third protected zone includes 6,940 ha, and the buffer zone includes 19,611 ha. Prohibited activities are defined at each level of protection. The highest level of protection, the first zone, bans any kind of exploitation of natural resources and all activities 


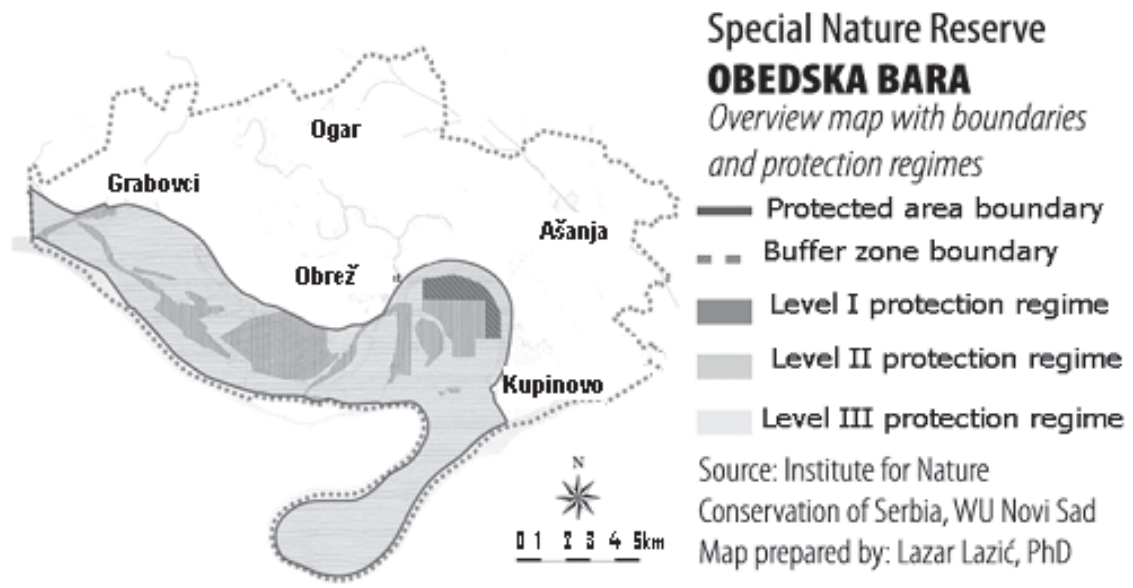

Fig. 2. Special Nature Reserve "Obedska Bara" with boundaries and protection regimes [17].

other than scientific and educational pursuits. Prohibited activities within the second protection zone are: changing the composition of forest ingredients and their exploitation; afforestation of ponds and meadows; maintenance of all activities that change the living conditions of the biota, water pollution, earthworks, vegetation changes, and the like.; hunting and fishing except when necessary to preserve the optimal number of animals and protect them from infectious diseases; the collection and use of protected plant and animal species; and the movement of people without special permission. Allowed activities in this area are: planned sanitary logging, silviculture, lawn mowing after July 15, presentation of the protected areas, monitoring of natural resources, and the establishment of monitoring.

Forbidden activities in the area of the third protection zone are: afforestation of ponds and meadows, the collection and use of protected plant and animal species, broadening of areas under the Euro-American poplars, cutting of individual trees and tree groups of native poplar and willow trees older than 30 years, works and other activities within $100 \mathrm{~m}$ of white-tailed eagle and black stork nesting sites, fishing in front of the inlet-outlet (discharge) channel $100 \mathrm{~m}$ from embarking or discharge. Allowed activities in the area of the third zone are: grazing of livestock in accordance with a grazing schedule, maintenance of hydraulic works for improvement of water regime, actions for improvement and preservation of environmental conditions, development of tourism, and construction of buildings in a traditional style in order to present the basic values of the area.

Prohibited activities in the buffer zone are: wastewater discharge, unplanned logging, uncontrolled use of fertilizers, and the unplanned construction of buildings. Allowed activities in the buffer zone are: building facilities for tourism and recreation, and hunting and fishing in accordance with hunting and fishing principles [18].

The Reserve is managed by the public company Vojvodinašume, based in Sremska Mitrovica with a branch in Kupinovo. The 2006 spatial plan for the Obedska Bara stated that local residents were key factors for sustainable development. However, this proposition is not completely applied in practice, which is the main reason for conflicts between local residents and authorities.

\section{Methodology}

Data collection about the attitudes of local residents toward Obedska Bara was carried out from June to September 2011 by personal interviews. The research was conducted in five villages in the area of the reserve: Grabovci, Kupinovo, Obrež, Ogar, and Ašanja. Three villages - Grabovci, Kupinovo, and Obrež - are located close to the boundaries of the reserve, while Ašanja and Ogar are situated in the buffer zone. Village locations, as well as their potentials for sustainable development, influenced residents' awareness and attitudes, which is the reason for comparison results between villages. The field data collection used 218 questionnaires on the basis of random sampling. Respondents were selected at different locations (along the roads in villages, in schools, offices, gardens, public transportation) to ensure randomization. Observing each village separately, the number of respondents was: Grabovci 36, Kupinovo 50, Obrež 52, Ogar 32, and Ašanja 48.

The questionnaire consisted of general questions (gender, age, birthplace, education, employment, and income) plus questions about the reserve. On the basis of the first group of questions, data about the socioeconomic structure of residents were received. These data in some cases correlated with answers in the second set of questions, which was determined on the basis of prior similar studies $[2,11]$ and adapted to local conditions. There were 18 multiple choice questions about the reserve in which respondents could give more answers or an additional answer to some of the questions. These 18 questions could be divided in four groups:

1) residents' awareness of the presence of the protected area (questions 1 and 2),

2) attitudes toward protection (3-9),

3) attitudes and financial benefits from tourists (10-12), 
Table 1. Demographic characteristic (results in \%)

\begin{tabular}{|c|c|c|c|c|c|c|c|}
\hline & Village & Grabovci & Ogar & Kupinovo & Obrež & Ašanja & Total \\
\hline \multirow{2}{*}{ Gender } & Male & 69.1 & 59.4 & 62 & 61.5 & 62.5 & 61.5 \\
\hline & Female & 38.9 & 40.6 & 38 & 38.5 & 37.5 & 38.5 \\
\hline \multirow{7}{*}{ Age } & $0-18$ & 0 & 15.6 & 10 & 3.8 & 20.8 & 10.1 \\
\hline & $19-29$ & 13.9 & 28.1 & 20 & 13.5 & 14.6 & 17.5 \\
\hline & $30-39$ & 36.1 & 18.7 & 16 & 9.6 & 16.7 & 18.3 \\
\hline & $40-49$ & 19.4 & 9.4 & 26 & 19.2 & 12.5 & 17.9 \\
\hline & $50-59$ & 5.6 & 15.6 & 14 & 28.8 & 22.9 & 18.3 \\
\hline & $60-69$ & 11.1 & 6.3 & 8 & 19.2 & 8.3 & 11 \\
\hline & $>70$ & 13.9 & 6.3 & 6 & 5.8 & 4.2 & 6.9 \\
\hline \multirow{2}{*}{ Birth place } & Indigenous & 77.8 & 80.6 & 87.8 & 85.4 & 83.3 & 83.5 \\
\hline & Settlementer & 22.2 & 19.4 & 12.2 & 14.6 & 16.7 & 16.5 \\
\hline \multirow{3}{*}{ Education } & Primary & 30.6 & 28.1 & 14 & 25 & 20.8 & 22.9 \\
\hline & Secondary & 47.2 & 53.1 & 74 & 59.6 & 70.9 & 62.4 \\
\hline & Faculty & 22.2 & 18.7 & 12 & 15.4 & 8.3 & 14.7 \\
\hline \multicolumn{2}{|c|}{ Persons with income } & 55.6 & 53.1 & 57.1 & 57.7 & 37.5 & 52.1 \\
\hline \multicolumn{2}{|c|}{ Persons without income } & 44.4 & 46.9 & 42.9 & 42.3 & 62.5 & 47.9 \\
\hline
\end{tabular}

4) proposals for sustainable development of the protected area (13-18):

Residents' awareness of the presence of the protected area included two questions:

- Do you know that the protected area is located in your municipality?

- Do you know where its boundaries are?

Attitudes toward protection involved the following questions:

- Is it important to protect a narrow belt close to the reserve?

- Would you vote for a candidate who plans to extend the protected area?

- Is safeguarding necessary in the reserve?

- Do you own land in the reserve?

- Should the owners of the land decide alone about the protection of their land?

- Which of the following should be limited: a) hunting, b) fishing, c) livestock raising, d) agriculture, e) logging?

- Is managed protection: a) good, b) bad), c) should be improved?

Attitudes and financial benefits from tourists contained three questions:

- Is the fact that the protected area attracts visitors:

a) pleasing, b) indifferent, c) disturbing?

Do you have any financial benefits from the visitors?

- If yes, what kind of benefits:

a) food stuff selling, b) services supply, c) other?

Proposals for sustainable development of the protected area consisted of the following questions:
- Which field would you prefer to be further developed in the protected area a) agriculture, b) fishery, c) forestry, d) tourism, e) other?

- In which field would you want to work: a) agriculture, b) fishery, c) forestry, d) tourism, e) other?

- What are the main obstacles for successful economy in the protected area: a) lack of better designed programs for visitors, b) lack of financial support for adequate infrastructure and professional services, c) absence of appropriate marketing, d) other?

- Would you prefer that this area: a) continue being protected, b) be declassified?

If the answer is "be declassified," explain why:

a) impossibility or difficulties for getting building permits,

b) impossibility or difficulties to sell land,

c) village/municipality will develop faster without the protected area,

d) the protected area makes the life of local residents difficult,

e) wild animals cause problems for local residents,

f) other?

What is your proposal for sustainable development of the protected area:

a) eco-tourism development,

b) landscape improvement,

c) development of allowed agricultural activities,

d) development of sport fishery,

e) educational programs for building local residents' awareness and knowledge about the protected area,

f) other? 
Table 2. Awareness of residents on the presence of the protected area (results in \%).

\begin{tabular}{|c|c|c|c|c|c|c|}
\hline & \multicolumn{2}{|c|}{$\begin{array}{c}\text { Do you know that a protected area is } \\
\text { located in your municipality? }\end{array}$} & \multicolumn{2}{|c|}{$\begin{array}{c}\text { Do you know where its boundaries } \\
\text { are? }\end{array}$} & $* \chi^{2}$ & $* * \mathrm{p}$ \\
\hline Village & Affirmative & Negative & Affirmative & Negative & 28.66246 & $\mathrm{p}=0.01$ \\
\hline Grabovci & 88.6 & 11.4 & 27.8 & 72.2 & & \\
\hline Ogar & 100.0 & 0 & 75.0 & 25.0 & & \\
\hline Kupinovo & 100.0 & 0 & 75.0 & 25.0 & & \\
\hline Obrež & 100.0 & 0 & 59.6 & 40.4 & & \\
\hline Ašanja & 100.0 & 0 & 77.1 & 22.9 & & \\
\hline Gender & & & & & 6.34218 & $\mathrm{p}=0.05$ \\
\hline Male & 98.5 & 1.5 & 70.5 & 29.5 & & \\
\hline Female & 95.2 & 4.8 & 53.6 & 46.4 & & \\
\hline
\end{tabular}

*Values of $\chi^{2}$ show significant correlation between variables; **p- level of signficance

Attitudes towards the protected area were analyzed using Chi square tests (Chi square goodness of fit and Chi square test of independence). Fishers' exact test was used when the comparison group had less than five respondents.

\section{Results and Discussion}

Demographic characteristics of respondents were similar in all villages in the area of the reserve, except for age structure (Table 1).

Regarding the awareness of the presence of the protected area, the majority of respondents were well informed, with the exception of Grabovci, where the majority of respondents did not know where the boundaries of the reserve were, and it was also the only village where some of the respondents were not aware of the presence of the protected area. This could be explained by its relative isolation compared to other places in the neighborhood, and by bad traffic connections. Gender influenced residents' awareness and attitudes. Males had a higher level of awareness of the protected area than females (Table 2), which is typical for small and closed environments where males are much more involved in all kinds of social activities than females.
The respondents had extremely positive attitudes toward protection. This statement refers especially to the respondents from Ogar, where all respondents thought that the narrow belt close to the Reserve should be protected, the protected area should be extended, and that safeguarding was necessary. These $100 \%$ affirmative answers of respondents from Ogar could be explained by the location of this village, which is not close to the boundary of the reserve, but a little further in the buffer zone, where more liberal principles of protection were established so the interests of local people were not in direct conflict with protection interests. Also, the majority of respondents from other villages answered these questions affirmatively.

This result is in line with most previous studies about protected areas around the world $[2,8,11]$. However, the positive attitude of respondents toward protection should also be explained by their insufficient knowledge of the protection regime. In additional conversations with the respondents it was found that they did not know what the expansion of the protected area would mean in practice and that they would not be willing to comply with new restrictions of resource use. This statement is confirmed by the respondents' answers that the owners of the land alone should decide about protection on their land. The respondents thought that the presence of Kupinik and

Table 3. Attitudes toward protection regarding villages (results in \%).

\begin{tabular}{|c|c|c|c|c|c|c|c|}
\hline & Village & Grabovci & Ogar & Kupinovo & Obrež & Ašanja & Total \\
\hline \multirow{5}{*}{$\begin{array}{l}\text { Which of the following should } \\
\text { be limited? }\end{array}$} & Hunting & 72.2 & 59.4 & 61.2 & 64.0 & 76.6 & 66.8 \\
\hline & Fishery & 66.7 & 59.4 & 42.8 & 50.0 & 57.4 & 54.2 \\
\hline & Livestock raising & 25.0 & 31.2 & 34.7 & 34.0 & 40.4 & 33.6 \\
\hline & Agriculture & 13.9 & 15.6 & 22.4 & 8.0 & 25.5 & 17.3 \\
\hline & Logging & 30.6 & 37.5 & 46.9 & 38.0 & 59.6 & 43.5 \\
\hline $\begin{array}{c}* \chi^{2} \\
* * \mathrm{p}=0.05\end{array}$ & 71.61388 & & & & & & \\
\hline
\end{tabular}

*Value of $\chi^{2}$ shows significant correlation between variables; **p- level of signficance 
Table 4. Attitudes toward protection regarding gender (results in $\%)$.

\begin{tabular}{|c|c|c|c|}
\hline & Gender & Male & Female \\
\hline $\begin{array}{c}\text { Would you vote for a } \\
\text { candidate who plans } \\
\text { to extend the protected } \\
\text { area? }\end{array}$ & Affirmative & 80.9 & 91.5 \\
\cline { 2 - 4 } & Negative & 19.1 & 8.5 \\
$* \begin{array}{c}* \\
\chi 2 \\
\end{array} 0.05$ & 4.394664 & & \\
\hline $\begin{array}{c}\text { Should the owners of } \\
\text { the land alone decide } \\
\text { about protection on } \\
\text { their land }\end{array}$ & Affirmative & 78.4 & 62.2 \\
\cline { 2 - 4 } & Negative & 21.6 & 37.8 \\
\hline$\chi 2$ & 6.624379 & & \\
\hline
\end{tabular}

*Values of $\chi^{2}$ show significant correlation between variables; $* *$ p- level of signficance

Obedska Bara hunting grounds had a negative impact on wildlife, so a high number of respondents thought that hunting should be limited (Table 3 ).

There were also differences in attitudes between males and females (Table 4). Males also had more positive attitudes than females, which can be explained in the same way as overall awareness. Gender influence on residents' attitudes was also present in other studies $[6,15]$.

The majority of respondents in all villages were not satisfied with managed protection and they thought that it should be improved. They mainly complained about the exploitation of the reserve on the part of the Vojvodinašume public company. They indicated that $60 \%$ of forest land was changed, because autochthonous forests of pedunculate oak (Quercus robur) were replaced by Canadian poplar (Populus canadiensis). Some of the respondents from Kupinovo thought that inadequate maintenance of the canal system caused fish mortality. Conflicts between local residents and authorities were presented in many previous studies $[4-6,11,16]$ so that this study is still one confirmation that cooperation between local residents and authorities as well as residents' participation in protected area management is necessary.

The large majority of the respondents (90.3\%) did not have any financial benefits from tourists. Despite this fact most of them had extremely positive attitudes toward tourists. Also, an extremely high number of respondents thought that tourism should be further developed and many of them desired to work in tourism. Women especially indicated tourism as a desired work field (Table 5). Resident attitudes toward tourism should be taken into account, considering that tourism development is a tool for reduction of conflicts between residents and authorities, and inclusion of residents in reserve management.

In spite of extremely positive attitudes toward protection and tourists, the respondents thought that there were many obstacles for successful economic development of the protected area (Table 6). More than half of all respondents thought that the biggest problem was the lack of financial support for appropriate infrastructure and professional services. The majority of respondents from Kupinovo thought that the main obstacle for a successful economy was lack of better designed programs for visitors. The fact that this attitude was partially different from those in other villages can be explained by Kupinovo's own

Table 5. Attitudes toward future economic development of the protected area (results in \%).

\begin{tabular}{|c|c|c|c|c|c|c|c|c|c|c|}
\hline & $\frac{8}{8}$ & $\begin{array}{l}\overline{0} \\
0 \\
0 \\
\tilde{0}\end{array}$ & $\begin{array}{l}\tilde{\tilde{E}} \\
0 \\
0\end{array}$ & 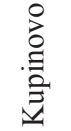 & 恣 & . & $\begin{array}{l}\overline{0} \\
\frac{\overrightarrow{0}}{0} \\
0\end{array}$ & $\frac{\frac{0}{\pi}}{\sum}$ & 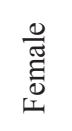 & 㔄 \\
\hline \multirow{5}{*}{$\begin{array}{l}\text { Which field would } \\
\text { you prefer be further } \\
\text { developed in the } \\
\text { protected area? }\end{array}$} & Agriculture & 16.7 & 15.6 & 30.6 & 17.3 & 16.7 & & 18.0 & 22.6 & 19.8 \\
\hline & Fishery & 22.2 & 53.1 & 44.9 & 51.9 & 33.3 & & 45.1 & 38.1 & 41.5 \\
\hline & Forestry & 16.7 & 37.5 & 22.5 & 23.1 & 25.0 & & 24.1 & 25.0 & 24.4 \\
\hline & Tourism & 75.0 & 90.6 & 91.8 & 88.5 & 89.6 & & 87.2 & 88.1 & 87.6 \\
\hline & Other & 2.8 & 3.1 & 4.1 & 5.8 & 6.2 & & 6.0 & 2.4 & 4.6 \\
\hline$* \chi^{2} * p^{*}=0.05$ & 264.3545 & & & & & & $* * * \mathrm{~ns}$ & & & \\
\hline \multirow{5}{*}{$\begin{array}{l}\text { In which field would } \\
\text { you want to work? }\end{array}$} & Agriculture & 22.9 & 25.0 & 9.5 & 11.6 & 13.3 & & 17.9 & 11.8 & 15.5 \\
\hline & Fishery & 22.9 & 21.4 & 9.5 & 13.2 & 22.2 & & 28.2 & 1.3 & 17.6 \\
\hline & Forestry & 11.4 & 14.3 & 9.5 & 11.6 & 11.1 & & 16.2 & 3.9 & 11.4 \\
\hline & Tourism & 48.6 & 46.4 & 80.9 & 74.4 & 71.1 & & 55.6 & 82.9 & 66.3 \\
\hline & Other & 5.7 & 3.6 & 4.8 & 4.7 & 6.7 & & 6.0 & 3.9 & 5.2 \\
\hline$\chi^{2}$ & 200.6429 & & & & & & 31.471 & & & \\
\hline
\end{tabular}

*Values of $\chi^{2}$ show significant correlation between variables; **p- level of signficance; ***not significant 
Table 6. Residents' perceptions of obstacles for successful economy of the protected area (results in \%).

\begin{tabular}{|c|c|c|c|c|c|c|}
\hline & \multicolumn{4}{|c|}{$\begin{array}{l}\text { What are the main obstacles for successful economy } \\
\text { in the reserve area? }\end{array}$} & \multirow{2}{*}{$\begin{array}{c}* \chi^{2} \\
98.19394\end{array}$} & \multirow{2}{*}{$\begin{array}{r}* * \mathrm{p} \\
0.05\end{array}$} \\
\hline Village & $\begin{array}{l}\text { Lack of better } \\
\text { designed program } \\
\text { for visitors }\end{array}$ & $\begin{array}{l}\text { Lack of financial support for } \\
\text { adequate infrastructure and } \\
\text { professional services }\end{array}$ & $\begin{array}{l}\text { Absence of appropriate } \\
\text { marketing }\end{array}$ & Other & & \\
\hline Grabovci & 19.4 & 75.0 & 13.9 & 5.6 & & \\
\hline Ogar & 50.0 & 56.3 & 37.5 & 6.3 & & \\
\hline Kupinovo & 66.0 & 58.0 & 40.0 & 10.0 & & \\
\hline Obrež & 39.2 & 58.8 & 56.9 & 7.8 & & \\
\hline Ašanja & 44.7 & 72.3 & 29.8 & 2.1 & & \\
\hline
\end{tabular}

*Value of $\chi^{2}$ shows significant correlation between variables; **p- level of signficance

tourist attractions (remnants of Kupinik medieval fortress, thermo-mineral springs, the monastery Obed, St. Lucas Church, ethno park, Church of the Venerable Mother Angelina, Kupinik hunting ground), which have not seen enough exposure to tourists [18]. More than half of the respondents from Obrež believed that the lack of adequate marketing was the main obstacle for successful economy of the protected area. This opinion also differs from opinion about marketing in other villages and it can be explained by the existence of Obrež Hotel, which could be crucial for the development of this village with appropriate marketing. In addition to these problems, the respondents stated a number of other problems that could be classified as inadequate management of the reserve, which led to conflicts between local residents and authorities. One respondent in each village indicated the problem of bad road quality and the "mentality of local residents."

Despite all these problems, the majority of respondents would prefer that this area stay protected, which again confirms the very positive attitude toward the protected area. In Ogar and Ašanja all respondents answered affirmatively, which, as aforementioned, could be explained by the fact that these villages are away from the boundaries of the reserve, i.e., they are located in the buffer zone and are not in direct conflict with the interests of protection. Among a few respondents who would prefer that the protected area should be declassified, most of them believed that the protected area made the life of local residents difficult. The majority of respondents thought that development of eco-tourism was most important for sustainable development of the protected area (Table 7). This result is in line with the previous answers where respondents said that tourism should be developed and that they would like to work in tourism. At the same time, this answer is further confirmation of the positive attitude of respondents toward tourism. More than half of the respondents from Kupinovo, Ašanja, and Obrež thought that the landscape should be improved. The respondents from Kupinovo and Obrež gave additional answers to the question about sustainable development. Primarily, they stated the importance of marketing and involvement of local residents in protection issues. Considering the locations and potentials of these two villages which are not exploited enough, it is logical that their residents were more interested in the development of the protected area compared to other adjacent villages.

Although the majority of the population works in agriculture, respondents did not find that agricultural

Table 7. Proposals for sustainable development of the protected area (results in \%).

\begin{tabular}{|c|c|c|c|c|c|c|c|}
\hline \multicolumn{7}{|c|}{ What is your proposal for sustainable development of the protected area? } & $\begin{array}{c}* \chi 2 \\
* * p=0.05\end{array}$ \\
\hline Village & $\begin{array}{c}\text { Eco-tourism } \\
\text { development }\end{array}$ & $\begin{array}{c}\text { Landscape } \\
\text { improvement }\end{array}$ & $\begin{array}{c}\text { Development of } \\
\text { allowed agricultural } \\
\text { activities }\end{array}$ & $\begin{array}{c}\text { Development } \\
\text { of sport } \\
\text { fishery }\end{array}$ & $\begin{array}{c}\text { Educative programs for } \\
\text { building awareness and } \\
\text { knowledge of local people } \\
\text { about the protected area }\end{array}$ & Other & 182.7381 \\
\hline Grabovci & 66.7 & 36.1 & 16.7 & 33.3 & 30.6 & 28.1 & 0 \\
\hline Ogar & 90.6 & 46.9 & 3.1 & 43.8 & 32.6 & 0 & 12.2 \\
\hline Kupinovo & 77.5 & 55.1 & 34.7 & 42.9 & 42.3 & 7.7 & \\
\hline Obrež & 75.0 & 61.5 & 11.5 & 32.6 & 47.9 & 0 & \\
\hline Ašanja & 70.8 & 64.6 & 14.6 & 12.2 & & \\
\hline
\end{tabular}

*Value of $\chi^{2}$ shows significant correlation between variables; **p- level of signficance 
development was important for the protected area. This result can be explained with the supposition that residents do not realize the desired benefits from this activity.

\section{Conclusions}

Surveying attitudes of local residents is one of the main prerequisites for successfully managing protected areas. In addition, involvement of local residents in different issues related to specific protected areas is very important. If local residents feel isolated and excluded, conflicts between them and protection authorities are frequent. On the example of Obedska Bara, the following conclusions can be inferred:

- The respondents have extremely positive attitudes toward the protected area. They think that the area should stay protected, that a narrow belt close to the reserve should be protected, and that safeguarding is necessary.

- Although they do not have any financial benefits from tourists, they show very positive attitudes toward tourists and tourism in general. The majority of respondents thought that tourism should be developed and they expressed a desire to work in tourism.

- Local residents are not satisfied with protection implementation, namely with management of the protected area. They think that local residents are excluded from all issues related to functioning of the reserve, that there is not enough financial support, that marketing is bad, and that there is no appropriate program for tourists. Due to the distrust toward authorities, local residents think that landowners alone should decide about protection on their land.

Hence, all those problems that exist in the protected areas where the interest of local residents is not taken in consideration are present. In order to change and remove at least part of the existing problems, a detailed survey of local residents should be carried out and, according to their knowledge and interest, conclude how they can contribute to protection. In any case, conflict would be reduced and cooperation between local residents and protection authorities would be improved, which is one prerequisite for the development of a protected area. Such conditions exist because local residents have positive attitudes toward the idea of protection.

The presented research method facilitates accurate interpretation of the results, which is crucial for its application in other similarly protected areas. This research method could also be applied by authorities of protected areas in communication with local residents, with the aim of preventing potential conflicts between these two parties and to help implement better management strategies.

\section{Acknowledgements}

This paper was realized as the part of the projects: "Geography of Serbia" (ID 47007) and "Biosensing
Technologies and Global System for Long-Term Research and Integrated Management of Ecosystems" (ID 43002), financed by Ministry of Education and Science, Government of the Republic of Serbia. The authors would like to thank the Institute for Nature Conservation of Serbia, WU Novi Sad and "Vojvodinašume" Public Company from Sremska Mitrovica for sharing the data, and Dr Boško Milovanović from Geographical Institute "Jovan Cvijić" Serbian Academy of Sciences and Arts for statistical data processing. Also, the authors would like to thank the local residents who took part in this survey.

\section{References}

1. MONDÉHAR-JIMÉNEZ J., MONDÉHAR-JIMÉNEZ J.A., VARGAS-VARGAS M., GÁZQUEZ-ABAD J.C. Personal attitudes in environmental protection. Int. J. Environ. Res. 6 (4), 1039, 2012.

2. CHRISTOPOULOU O.G., TSACHALIDIS E. Conservation polices for protected areas (wetlands) in Greece: a survey of local residents' attitude. Water Air Soil Pollut.: Focus 4, 456, 2004.

3. ALLENDORF T.D. Residents' attitudes toward three protected areas in southwestern Nepal. Biodivers. Conserv. 16, 2088, 2007.

4. MÉNDEZ-CONTRERAS J., DICKINSON F., CASTILLOBURGUETE T. Community member viewpoints on the Ría Celestún Biosphere Reserve, Yucatan, Mexico: suggestions for improving the community/natural protected area relationship. Hum. Ecol. 36, 112, 2008.

5. HAUSSER Y., WEBER H., MEYER B. Bees, farmers, tourists and hunters: conflict dynamics around Western Tanzania protected areas. Biodivers. Conserv. 18, 2679, 2009.

6. OGRA M. Attitudes toward resolution of human - wildlife conflict among forest - dependent agriculturalists near Rajaji National Park, India. Hum. Ecol. 37, 161, 2009.

7. BONAIUTO M., CARRUS G., MARTORELLA H., BONNES M. Local identity processes and environmental attitudes in land use changes: The case of natural protected areas. J. Econ. Psychol. 23, 636, 2002.

8. DIMITRAKOPOULOS P.G., JONES N., IOSIFIDES T., FLOROKAPI I., LASDA O., PALIOURAS F., EVANGELINOS K.I. Local attitudes on protected areas: Evidence from three Natura 2000 wetland sites in Greece. J. Environ. Manage. 91, 1847, 2010.

9. HOVARDAS T, STAMOU G.P. Structural and narrative reconstruction of rural residents' representations of 'nature', 'wildlife', and landscape. Biodivers. Conserv. 15, 1745, 2006.

10. GÖTHARD F., SÖDERLUNDH H., THORELL M. Buffer zones for forest reserves: opinions of land owners and conservation value of their forest around nature reserves in southern Sweden. Biodivers. Conserv. 9, 1377, 2000.

11. GRODZINSKA-JURCZAK M., CENT J. Expansion of nature conservations areas: problems with Natura 2000 implementation in Poland? Environ. Manage. 47, 11, 2011.

12. PETROVA S., ČIHAŘ M., BOUZAROVSKI S. Local nuances in the perception of nature protection and place attachment: a tale of two parks. Area 43 (3), 327, 2011.

13. ŠVAJDA J., FENICHEL E.P. Evaluation of Integrated Protected Area Management in Slovakian National Parks. Pol. J. Environ. Stud. 20 (4), 1554, 2013. 
14. POREJ D., PIŠČEVIĆ N., ORLOVIĆ-LOVREN V. Protected area management effectiveness in Serbia. Final report of RAPPAM Analysis. Ministry of Environment and Spatial Planning of Republic of Serbia and Mediterranean Programme WWF, Belgrade, 2009 [In Serbian].

15. TOMIĆEVIĆ J., SHANNON M.A., MILOVANOVIĆ M. Socio-economic impacts on the attitudes towards conservation of natural resources: Case study from Serbia. Forest Policy Econ 12, 157, 2010.

16. TOMIĆEVIĆ J., BJEDOV I., OBRATOV-PETKOVIĆ D., MILOVANOVIĆ M. Exploring the park-people relation: collection of Vaccinium Myrtillus L. by local people from Kopaonik National Park in Serbia. Environ. Manage. 48, 835, 2011.
17. LAZIĆ L., PAVIĆ D., STOJANOVIĆ V., TOMIĆ P., ROMELIĆ J., PIVAC T., KOŠIĆ K., BESERMENJI S., KICOŠEV S., ĐARMATI Z., PUZOVIĆ S., ĐUREŠKOVIĆ-TEŠIĆ O., STOJANOVIĆ T., MARIĆ B., VIG L., PANJKOIĆ B., HABIJAN-MIKEŠ V., SABADOŠ K., DELIĆ J., KOVAČEVIĆ B., STOJŠIĆ V., KORAĆ J. Protected natural assets and ecotourism in Vojvodina, 2nd revised edn, Faculty of sciences, Department of geography, tourism and hotel management, Novi Sad, 2008.

18. PUZOVIĆ S., STOJANOVIĆ T., VIG L., MARIĆ B., ĐUREKOVIĆ-TEŠIĆ O., DOBRETIĆ V., STOJŠIĆ V., LAZIĆ L., STOJANOVIĆ V., PAVIĆ D. Ramsar sites of Vojvodina, Obedska Bara. Provincial Secretariat for Environmental Protection and Sustainable Development, Novi Sad, 2010 [In Serbian]. 